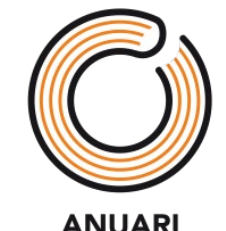

DE BIBLIOTEQUES,

LLIBRES I LECTURA

Elisabet Serra

Laia Vidal

lecturafacil@cobdc.org

Associació Lectura Fàcil

\title{
LA LECTURA FÀCIL \\ A CATALUNYA (2018-2019)
}

LA LECTURA FÁCIL
EN CATALUÑA (2018-2019)

EASY-TO-READ INITIATIVES

IN CATALONIA (2018-2019) 


\section{RESUM | RESUMEN | ABSTRACT}

Durant els anys 2018 i 2019 la lectura fàcil s'està consolidant al nostre territori. L'accessibilitat als continguts, és a dir, fer la informació més accessible pensant en les persones amb dificultats lectores, s'està obrint pas en molts sectors que fins ara no ho tenien com a prioritat. És el cas d'administracions, biblioteques, museus, teatres i la cultura en general. Però en d'altres àmbits, com ara el judicial, continua faltant un impuls per fer arribar els seus continguts de manera planera a tota la ciutadania. En tots els àmbits, però, manca una institució que inclogui l’accessibilitat cognitiva com a eix transversal en tota la seva comunicació.

Durante los años 2018 y 2019 la Lectura Fácil se está consolidando en nuestro territorio. La accesibilidad a los contenidos, es decir, favorecer una información más accesible pensando en las personas con dificultades lectoras, se está abriendo paso en muchos sectores que hasta ahora no lo tenían como una de sus prioridades. Es el caso de administraciones, bibliotecas, museos, teatros y de la cultura en general. Pero en otros ámbitos, como por ejemplo el judicial, sigue faltando un impulso para hacer llegar sus contenidos de manera sencilla a toda la ciudadanía. En todos los ámbitos, sin embargo, falta una institución que incluya la accesibilidad cognitiva como eje transversal en toda su comunicación.

In 2018 and 2019, Easy-to-read materials have continued to establish themselves in Catalonia. Many institutions - libraries, museums, theatres and culture in general - now acknowledge the importance of providing access to comprehensible materials for people with reading difficulties. But in other areas, such as the law, few attempts have been made to make content accessible to all people in a straightforward way. There is a clear need for an institution that regards cognitive accessibility as a priority in all aspects of its communication.

PARAULES CLAU:

Lectura fàcil, Associació Lectura Fàcil, Persones amb dificultats lectores,

Accessibilitat informativa

PALABRAS CLAVE:

Lectura fácil, Asociación Lectura Fácil, Persones con dificultades lectoras,

Accesibilidad informativa

\section{KEYWORDS:}

Easy-to-read, Associcació Lectura Fàcil, People with reading difficulties, Information accessibility 


\section{PRESENTACIÓ}

L'embranzida de la lectura fàcil és una realitat, i així ho hem pogut constar durant el 2018 i 2019. A Catalunya, l'Associació Lectura Fàcil (ALF) ha celebrat quinze anys de trajectòria $i$ ha reunit els principals representants que promouen la lectura fàcil $i$ el llenguatge planer a Europa. A escala internacional, també s'han organitzat diverses iniciatives per donar a conèixer la lectura fàcil, un moviment per democratitzar la lectura i fer arribar la cultura, la literatura i la informació a totes les persones, en especial a les que tenen dificultats lectores.

A casa nostra, la lectura fàcil segueix l'impuls forjat els darrers anys: creixen els clubs de lectura en biblioteques i entitats socials, i amb ells, la necessitat d'ampliar el catàleg amb més títols. En el sector educatiu, però, l'ús dels llibres de lectura fàcil com a recurs per treballar la comprensió lectora segueix sent una assignatura pendent. El Decret 150/2017, de 17 d'octubre, de l'atenció educativa a l'alumnat en el marc d'un sistema educatiu, hauria de ser l'estímul necessari perquè els llibres i els continguts curriculars accessibles siguin una realitat. Durant el 2018-2019 s'han fet petites passes en aquest sentit.

El treball de l'ALF amb biblioteques, centres educatius i el teixit associatiu segueix fent créixer el nombre de clubs de lectura fàcil arreu del territori. Com a conseqüència, també creix la demanda de més títols i noves publicacions adaptades. Cal engrescar, doncs, més editorials perquè se sumin a l'edició inclusiva, perquè deixin de veure la lectura fàcil amb desconfiança i la vegin com una oportunitat per obrir-se a nous públics.

Les editorials que hi han apostat durant aquests anys ho segueixen fent, $\mathrm{i}$ obren nous mercats en altres llengües de l'Estat, com l'eusquera i el gallec.

Però la lectura fàcil va més enllà de la literatura $i$ el foment lector. L'accessibilitat als continguts va prenent força, i cada vegada són més les administracions $\mathrm{i}$ institucions que ofereixen continguts adaptats, accessibles a tothom.

La Llei 13/2014, del 30 d'octubre, d'accessibilitat continua esperant el desplegament del Decret que la faci del tot vigent, però museus i administracions locals han pres la iniciativa d'adaptar els seus continguts de forma clara i accessible. Segueix faltant, però, administracions que prevegin l'accessibilitat cognitiva de manera transversal, com un eix vertebrador de totes les seves àrees.
A Catalunya,

I'Associació Lectura

Fàcil (ALF) ha

celebrat quinze anys

de trajectòria i ha

reunit els principals

representants que

promouen la lectura

fàcil i el llenguatge

planer a Europa

\section{L'accessibilitat als}

continguts va prenent

força, i cada vegada

són més les

administracions $i$

institucions que

ofereixen continguts

adaptats, accessibles

a tothom.

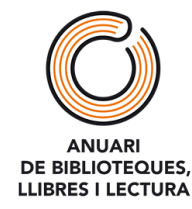


El treball en xarxa és un dels objectius fundacionals de l'Associació Lectura Fàcil. Durant l'any 2019 la Xarxa de Lectura Fàcil s'ha ampliat amb dues noves associacions, Lengua Franca de l'Argentina i Palabras Claras de Colòmbia. D'aquesta manera, la xarxa obre fronteres $i$ enforteix els vincles amb les associacions que promouen la lectura fàcil i l'accessibilitat cognitiva arreu del món.

\subsection{Amèrica del Sud}

L'afinitat d'idioma ha permès que els països sud-americans es fixin en l'Associació Lectura Fàcil com a experiència a replicar. Les realitats diverses entre aquests països i Catalunya són evidents, però els inicis tenen moltes semblances. Des de l'ALF s'han assessorat les entitats i institucions que hi han contactat sobre com implantar la lectura fàcil des de zero. La primera necessitat és disposar de llibres de lectura fàcil. La importació de llibres pot ser una solució, però no totes les editorials del catàleg en poden fer. La temàtica dels llibres, les diferències en el vocabulari i el canvi de valor de les divises, també són factors en contra. Per això, el primer pas sol ser crear continguts propis.

L'Associació Lengua Franca de l'Argentina va ser la primera. Alguns membres de l'entitat van viatjar a Barcelona per conèixer de prop l'experiència de l'ALF i formar-se en l'adaptació de materials. El projecte inicial de l'entitat ha estat la col-lecció "Cinco cuentos», de relats breus d'autors argentins adaptats a lectura fàcil. El setembre de 2018, l'ALF viatjava a Buenos Aires per parlar sobre la lectura fàcil a la Primera Trobada Internacional de Bones Pràctiques de Lectura Fàcil. Per a l'Associació argentina, l'experiència catalana ha estat un referent on emmirallar-se i començar el propi camí.

A Colòmbia la lectura fàcil també ha despertat interès durant el 2019. L'entitat Palabras Claras va contactar amb l'ALF per donar a conèixer els materials adaptats a professionals que treballen amb col-lectius amb dificultats lectores. Alguns membres de l'entitat van participar en formacions en línia impartides per l'ALF i van editar el llibre Amores y mujeres en la independencia, un recull de relats de l'autora colombiana Soledad Acosta de Samper. Posteriorment, i gràcies a la intermediació de Palabras Claras, la Cámara Colombiana del Libro va convidar I'ALF a la 32a Feria Internacional del Libro de Bogotá (FilBo) per parlar sobre la lectura fàcil i oferir una formació en tècniques de redacció a professionals dels sectors educatiu i editorial.

En el cas de la República Dominicana, l'interès va arribar de part del Ministerio de Educación, el Despacho de la Primera Dama del país i I'Organización de Estados Iberoamericanos (OEI), que van convidar l'ALF a presentar la seva experiència i la seva feina en el Seminario Iberoamericano de Estrategias de Apoyo para la Educación Inclusiva, una trobada amb professors per donar a conèixer la lectura fàcil i com aplicar-la a l'aula. La
El treball en xarxa és un dels objectius fundacionals de I’Associació Lectura Fàcil

L'afinitat d'idioma ha permès que els països sud-americans es fixin en l'Associació Lectura Fàcil com a experiència a replicar 
realitat del país i la mancança d'un teixit associatiu no ha permès, de moment, establir una col·laboració per adaptar materials ni per implantar el projecte al territori.

Una altre cas especial és el de Salvador. Des de fa temps la Unidad Técnico Ejecutiva del Sector Justicia col-labora amb I'ALF en l'adaptació a lectura fàcil de diversos textos legals. Durant el 2018-2019 s'ha treballat en I'adaptació d'un conjunt de lleis importants per al país. Si bé l'adaptació de lleis és una pràctica bastant habitual en països llatinoamericans, no ho és tant a Espanya i Catalunya.

De totes aquestes experiències, es fa evident que per instaurar un projecte estable i permanent en l'àmbit nacional o internacional cal disposar d'una entitat sòlida que el lideri. Quan el contacte inicial s'estableix amb administracions, el projecte es veu reduït a propostes concretes (participació en una jornada, adaptació de materials, etc.).

\subsection{Europa}

Si als països d'Amèrica Llatina la lectura fàcil ha experimentat un auge durant aquests anys, a Europa és moment de canvis.

El més notori ha estat la conversió del Centrum för lättläst de Suècia, el centre de referència des d'on es van gestar les bases de la lectura fàcil, en una agència de mitjans accessibles (MTM: Myndigheten för tillgängliga medier), que depèn del Ministeri de Cultura suec. Aquesta agència crea $i$ proporciona tota mena de recursos (llibres, diaris, documents, etc.) en formats accessibles (lectura fàcil, braille...) a biblioteques i escoles, i s'ha convertit en una institució pública governamental.

Aquest canvi ha comportat la inacció de l'Easy to Read Network, que es va crear a Barcelona l'any 2005, quan l'ALF va organitzar la primera trobada internacional. Aquesta entitat feia alguns anys que es mantenia inactiva. Lluny queden els anys on la xarxa es reunia periòdicament. La seva finalització deixa un buit en la posada en comú dels projectes internacionals en relació amb la lectura fàcil.

La resta d'entitats de lectura fàcil europees han continuat el seu recorregut, com per ara Finlàndia, Noruega o Alemanya.

\subsection{Territori nacional}

La falta de lideratge europeu va portar a l'ALF a intentar reorganitzar i impulsar una nova xarxa internacional i buscar noves aliances. El 2018 l'ALF celebrava el quinzè aniversari, i tenia la força i la consolidació suficient per emprendre aquest projecte.

Per aquest motiu, a finals del 2019 va organitzar la Segona Trobada Internacional de Lectura Fàcil a Barcelona. A la Jornada hi van participar
Es fa evident que per

instaurar un

projecte estable i

permanent en

l'àmbit nacional o

internacional cal

disposar d'una

entitat sòlida que el

lideri

El Centrum för

lättläst de Suècia, el

centre de referència

des d'on es van

gestar les bases de

la lectura fàcil... s'ha

convertit en una

institució pública

governamental 
dinou ponents de set països diferents. L'objectiu era conèixer la realitat de la lectura fàcil a diversos països i sectors: biblioteques, centres culturals, Administració... L'acte va tenir una gran acollida, i s'hi van establir les bases per tornar a emprendre una nova aliança internacional.

Les Trobades de Lectura Fàcil s'organitzen des del 2013 en col·laboració amb la Xarxa de Lectura Fàcil. Aquesta xarxa va néixer per aglutinar les associacions que sorgeixen a l'Estat espanyol i que utilitzaven el segell LF com a distintiu. A poc a poc la Xarxa ha anat creixent, fins a comptar amb deu membres. L'any 2019 s'hi van unir les associacions Lengua Franca d'Argentina i Palabras Claras de Colòmbia, el primer pas per a la internacionalització d'aquesta xarxa.

\section{FOMENT DE LA LECTURA: QUINZE ANYS FENT NOUS LECTORS}

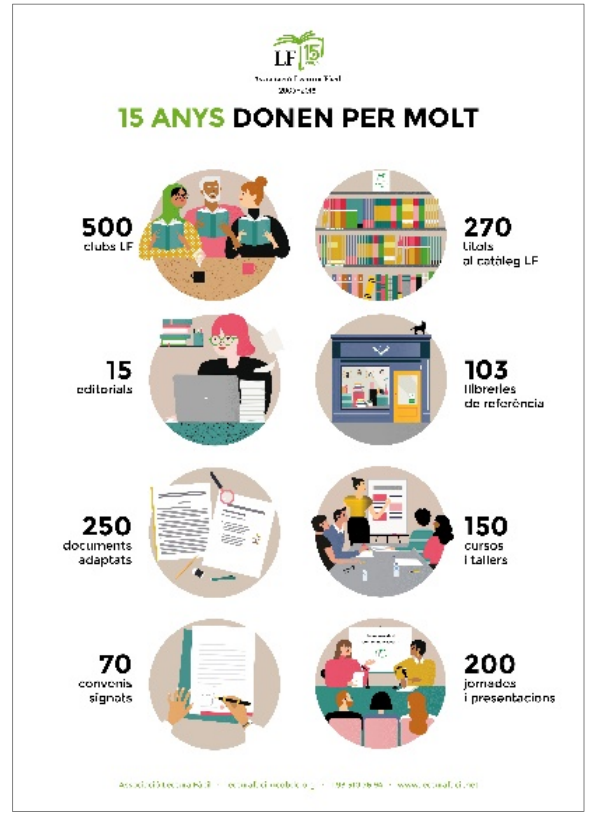

El 2018 va suposar un punt d'inflexió de la lectura fàcil al nostre territori. Es complien quinze anys de la creació de l'Associació Lectura Fàcil, i el seu bagatge, experiència reconeixement i el de la lectura fàci al territori, estaven consolidats. Les dades així ho demostren:

Dins els actes de commemoració dels quinze anys de l'ALF, es va organitzar la campanya "Motius de ser de la Lectura Fàcil». Mes rere mes, vam recollir al nostre web l'escrit de professionals, d'àmbits molt diferents, que ens explicaven els motius pels quals se senten vinculats amb la lectura fàcil. Entre els professionals que hi van participar destaquem: Glòria Pérez-Salmerón, presidenta de I'IFLA; Ester Franquesa, directora general de la Direcció General de Política Lingüística; Anna Sans, neuròloga infantil; Inma Chacón, escriptora; Irene Calvís, responsable del projecte social del Liceu; Xavier Díaz, director de l'ICEC, i Marga Losantos, presidenta del COBDC.

L'any es va clausurar amb una trobada festiva que va servir per repassar la trajectòria, reflexionar sobre el futur i reunir totes aquelles persones, entitats $\mathrm{i}$ institucions que han ajudat a consolidar la lectura fàcil al nostre país.

\subsection{Biblioteques: el gran pilar de la lectura fàcil}

A finals del 2019 va organitzar la Segona Trobada Internacional de Lectura Fàcil a Barcelona

\section{Dins els actes de} commemoració dels quinze anys de l'ALF, es va organitzar la campanya "Motius de ser de la Lectura Fàcil» 
Les biblioteques han estat i continuen sent el gran pilar de la lectura fàcil. Ens referim, per una banda, als acords institucionals amb Biblioteques de Barcelona, la Xarxa de Biblioteques Municipals de la Diputació de Barcelona i el Servei de Biblioteques del Departament de Cultura de la Generalitat de Catalunya i, per l'altra, a la conscienciació del personal de les biblioteques del paper integrador de la lectura fàcil a favor d'una biblioteca inclusiva $i$ social.

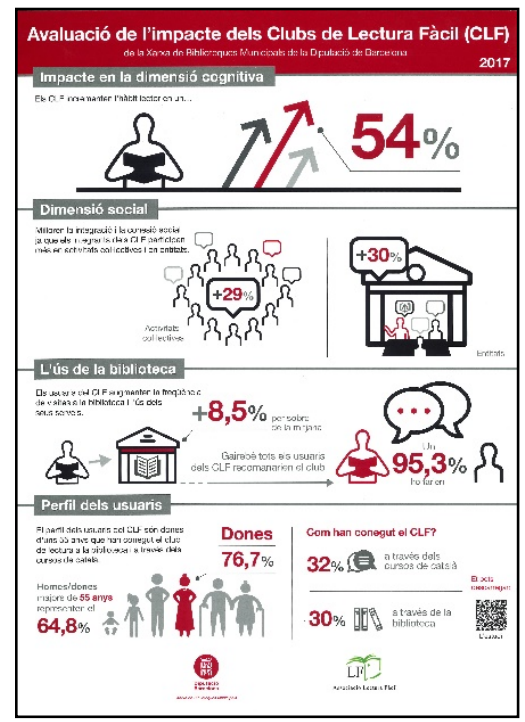

La Gerència de Serveis de Biblioteques de la Diputació de Barcelona va encarregar el 2017 un estudi per avaluar l'impacte social i cognitiu dels clubs de lectura fàcil (Avaluació dels clubs de lectura fàcil, 2018). Aquests clubs han tingut una evolució molt favorable i s'han estès arreu del territori oferint una porta d'accés a la lectura i la cultura a persones amb dificultats lectores. Però després de quinze anys, quin impacte han tingut aquests clubs entre els seus usuaris? El 2018 en vam saber els resultats, i ens confirmaven que "els clubs de lectura fàcil són una eina per millorar la confiança i facilitar la integració social, la cohesió i la participació de segment socials que podrien trobar barreres; al mateix temps que són una eina per evitar l'avorriment i l'isolament social, són un espai que permet als participants compartir, trencar amb la rutina i expressar sentiments i emocions.» (Avaluació dels clubs de lectura fàcil, 2018).

L'estudi conclou que «els clubs de lectura Fàcil tenen un impacte en àmbits rellevants per a la política pública, de manera que es podrien considerar una eina de la política educativa, cultural i social i, a més, una estratègia de comunicació i promoció de públics per a les biblioteques.» (Avaluació dels clubs de lectura fàcil, 2018).

Per la seva banda, el Servei de biblioteques de la Generalitat de Catalunya continua apostant pel projecte Biblioteques Inclusives, en el qual I'ALF hi col-labora estretament des d'un principi.

Aquest projecte va néixer «amb l'objectiu d'establir uns mínims per aconseguir que totes les biblioteques públiques catalanes siguin espais inclusius, no només per complir amb tot el marc legal i teòric, sinó per donar oportunitat de futur a totes les persones amb discapacitat per tal de garantir la seva plena inserció a la societat». El Projecte està integrat per quatre grups de treball: Arquitectura, Fons documental i material de suport, Activitats i serveis, i Formació.

El 2018 l'ALF va col-laborar en l'organització de la Segona Jornada de Biblioteques Inclusives, i en la redacció de les Pautes d'accessibilitat per a biblioteques públiques.
Les biblioteques han estat i continuen sent el gran pilar de la lectura fàcil

La Gerència de Serveis de Biblioteques de la Diputació de Barcelona va encarregar el 2017 un estudi per avaluar l'impacte social $i$ cognitiu dels clubs de lectura fàcil

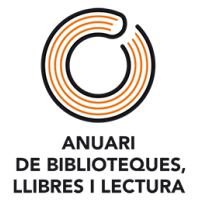


Els llibres de lectura fàcil són una de les eines de què disposa una biblioteca per ser més accessible. Cal que els professionals que hi treballen els coneguin, i els sàpiguen ubicar i recomanar als usuaris. Recordem que les persones usuàries de lectura fàcil són collectius poc assidus a les biblioteques, i cal fer un esforç per atraure'ls i donar-los a conèixer el fons accessible.

També en aquest sentit, l'ALF ha assessorat Biblioteques de Barcelona per formar bibliotecaris i donar-los a conèixer les possibilitats de la lectura fàcil com a eina d'inclusió social i d'accessibilitat cognitiva.

\subsection{Clubs i llibres de lectura fàcil}

Arreu del territori català hi ha més de dos-cents clubs que utilitzen llibres de lectura fàcil (cinc-cents a l'Estat espanyol). És una xarxa de lectura extensa en la qual participen biblioteques, entitats, escoles, centres de normalització lingüística, etc., que han fet que la lectura esdevingui una activitat de plaer per a moltes persones, amb independència de la seva condició. Cada un dels cinc-cents clubs és un espai de socialització i cohesió social, un espai que dona la possibilitat d'adquirir el gust per la lectura a persones que ho havien donat per perdut o que mai n'havien tingut l'oportunitat, i també un espai que obre la biblioteca a un públic que no la freqüenta.

Parlem de xarxa de lectura perquè són necessàries moltes complicitats per garantir-ne el bon funcionament:

- Autors i editorials que contribueixen a crear un fons de llibres de lectura fàcil. Actualment el catàleg consta de tres-cents títols avalats amb el segell LF que atorga l'ALF.

- Biblioteques i entitats socials que donen a conèixer aquests llibres $i$ organitzen clubs de lectura fàcil.

- Centres dipositaris de lectura fàcil, que compren lots de llibres i els ofereixen en préstec als clubs de lectura fàcil.

- Dinamitzadors de clubs de lectura, la majoria de persones voluntàries que fomenten $\mathrm{i}$ acompanyen la lectura setmana rere setmana.

- Lectors que han descobert el plaer de llegir gràcies als clubs $i$ als llibres de lectura fàcil.

- Administracions que col-laboren en les activitats de foment lector organitzades per l'ALF.

L'augment de clubs de lectura fàcil va unit a una demanda de nous títols adaptats que diversifiquin l'oferta del catàleg. És estrany que un club de lectura fàcil desaparegui un cop iniciat. Així doncs, existeixen clubs amb una gran trajectòria i que necessiten nous títols per continuar i no repetir lectura.

Si bé el nombre de títols publicats augmenta cada any, encara hi trobem a faltar obres d'autors actuals que siguin un reclam per a lectors joves i adults. També som conscients de la necessitat d'oferir obres d'autors catalans que
Les persones usuàries de lectura fàcil són col/lectius poc assidus a les biblioteques, i cal fer un esforç per atraure'ls i donar-los a conèixer el fons accessible

\section{Arreu del territori català hi ha més de dos-cents clubs que utilitzen llibres de lectura fàcil}


en reforcin la solidesa literària i alhora siguin un referent per donar a conèixer el país. El problema segueix sent l'accés a aquests títols pels quals les editorials demanen uns drets d'autor inassolibles per a les editorials que publiquen en lectura fàcil.

En aquest sentit, entre el 2018 i 2019 hem adaptat Pilar Prim, de Narcís Oller, Joc brut i Massa boira i altres contes, de Manuel de Pedrolo, L'auca del senyor Esteve, de Santiago Rusiñol o Bearn o la sala de les nines, de Llorenç Villalonga.

Una de les novetats del catàleg ha estat la incorporació de títols en eusquera i en gallec, una aposta decidida de les editorials que ja publiquen en català i castellà. Aquest fet també ha incrementat les vendes i les activitats de foment lector a les comunitats autònomes on es parlen aquestes llengües.

\subsection{Educació: assignatura pendent}

Però si la lectura fàcil es consolida al món bibliotecari i social, al món educatiu segueix sent una assignatura pendent. Manca una política estable i efectiva per crear materials educatius accessibles per a tot l'alumnat, en especial per a aquells alumnes amb dificultats de comprensió lectora. I no només de textos literaris, sinó també de materials curriculars. Ara per ara, només hi ha iniciatives aïllades sorgides arran de necessitats concretes de l'alumnat. Això dificulta poder compartir els materials adaptats entre els diferents centres.

El Decret 150/2017, de 17 d'octubre, de l'atenció educativa a l'alumnat en el marc d'un sistema educatiu inclusiu hauria de ser l'impuls perquè aquests exemples no quedin aïllats i la lectura fàcil es converteixi en material d'inclusió, una eina i un recurs per a tots els alumnes i docents. Tot i això, s'han començat a donar passes endavant, com la Jornada «Lectura Fàcil, un recurs per a l'escola inclusiva" organitzada amb el Departament d'Educació el juliol del 2019. Una setantena de mestres hi van participar per conèixer experiències d'èxit, recursos i exemples de com treballar els llibres de lectura fàcil a l'aula.

Amb l'objectiu de posar a l'abast de centres educatius i entitats tots els recursos i documents en lectura fàcil, des de l'ALF s'ha creat un repositori web amb més de quatre-centes referències d'accés lliure classificades en diverses tipologies: suport curricular (enunciats d'exàmens, temaris i recursos didàctics), documents adaptats (sobre diverses matèries: salut, cultura, lleis, etc.), suport a la lectura o bibliografia. El repositori incorpora un cercador per trobar de forma àgil i senzilla un document per tipologia, matèria o idioma.

En els últims anys, el web de l'ALF s'ha convertit en un punt de referència i consulta per als professionals que treballen amb persones amb dificultats lectores en escoles, entitats, biblioteques, etc. L'any 2019 va rebre cinquanta mil visites.
Si la lectura fàcil es consolida al món bibliotecari i social, al món educatiu segueix sent una assignatura pendent

Des de l'ALF s'ha creat un repositori web amb més de quatrecentes referències d'accés lliure classificades en diverses tipologies

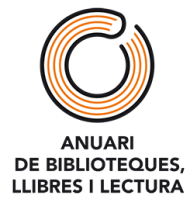




\section{ALTRES SECTORS: ACCESSIBILITAT COGNITIVA}

La democràcia lectora és el paraigua que engloba la lectura fàcil: fer que la cultura, la lectura i la informació siguin accessibles i comprensibles per a totes les persones. Més enllà del foment lector, la lectura fàcil també té un gran recorregut. L'adaptació de continguts informatius, administratius, culturals, etc., s'ha obert camí, amb els museus al capdavant.

\subsection{Administracions}

La Llei 13/2014, del 30 d'octubre, d'accessibilitat de Catalunya comença a donar fruits, tot i que encara falta l'aprovació del decret que la faci efectiva. La Llei preveu l'elaboració d'un decret de desplegament que determinés els requisits i criteris per al seu compliment. Durant el 2019 es va presentar el projecte de decret, sobre el qual les entitats i la societat en general podien presentar esmenes. Haurem d'esperar a l'aprovació final d'aquest decret perquè entrin en vigor totes les mesures d'accessibilitat que promou la Llei, entre elles, l'obligatorietat dels serveis públics d'adaptar els documents a la lectura fàcil.

Malgrat que encara no hi ha el marc legal consolidat, algunes administracions preveuen l'accessibilitat cognitiva i adapten els documents d'especial interès per a la ciutadania. És el cas de la Generalitat de Catalunya, i els d'alguns ajuntaments, com ara el de Sabadell, Sant Just Desvern, Figueres, etc.; també institucions com l'Àrea Metropolitana de Barcelona, I'Institut Municipal de Persones amb Discapacitat de Barcelona (IMPD) o l'Agència de Salut Pública de Barcelona (ASPB).

Alguns exemples de documents adaptats són:

- Àrea Metropolitana de Barcelona (AMB): Infografies amb dades sobre discapacitat a l'AMB

- Ajuntament de Barcelona: Directiva sobre igualtat de tracte a la feina il'ocupació

- Ajuntament de Figueres: Tríptic de la Xarxa d'acollida de nouvinguts

- Ajuntament de Sant Just Desvern: Documents sobre ajudes socials per a l'IB|

- Ajuntament de Sabadell: Tríptic sobre el Consell de Participació dels Infants

A finals de 2019 la Generalitat de Catalunya va convocar oposicions del cos de subaltern reservades a persones amb discapacitat intel-lectual. L'ALF i la Federació Catalana de Discapacitat Intel-lectual (Dincat) van treballar
La Llei 13/2014, del 30

d'octubre, d'accessibilitat de

Catalunya comença a donar fruits

\section{A finals de 2019 la Generalitat de Catalunya va} convocar oposicions del cos de subaltern reservades a persones amb discapacitat intel-lectual. L'ALF va treballar per adaptar el temari

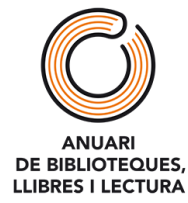


conjuntament per adaptar el temari. Era la primera vegada a Catalunya que una administració adaptava el contingut d'una convocatòria d'oposicions.

Però tot i aquests exemples, manca que l'Administració inclogui l'accessibilitat als continguts com a eix transversal en tota la seva organització. Fins ara, han estat adaptacions de documents concrets, o projectes d'una regidoria o àrea concreta. Però allò realment eficaç seria incorporar la lectura fàcil i l'accessibilitat als documents més rellevants de tota l’Administració.

Catalunya havia estat pionera en l'adaptació de continguts administratius, però l'impuls de la lectura fàcil a altres comunitats autònomes, ha fet créixer iniciatives més transversals i contundents. Un exemple és el Plan de Lectura Fácil de l'Ayuntamiento de Bilbao, un pla de tres anys de durada, que inclou formació en lectura fàcil per al personal municipal; l'adaptació i validació dels documents de més impacte ciutadà de cada àrea, i l'habilitació d'un espai comú per compartir els documents elaborats en lectura fàcil.

\subsection{Equipaments culturals}

La cultura ha estat el sector que més esforços ha dedicat per crear materials accessibles. Molts equipaments culturals han demanat la col-laboració de l'ALF per adaptar textos de sala, catàlegs i dossiers educatius per tal de garantir l'accessibilitat cognitiva en les seves exposicions.

És el cas de museus com:

- Patronato de la Alhambra y Generalife: Guía de la Dobla de oro y La Alhambra

- MUSAC: diferents exposicions

- Museu de l'Empordà: diferents exposicions

En aquesta línia de promoció de l'accessibilitat als continguts museístics, el 2018 va tenir lloc el 5è Congrés Internacional Educació i Accessibilitat a Museus i Patrimoni. L'Associació Lectura Fàcil hi va presentar el treball d'adaptació de les cartel-les de l'exposició permanent del Museu Botànic de Barcelona.

Al marge dels museus, destaca amb especial atenció la voluntat del Gran Teatre del Liceu per millorar l'accessibilitat i la comprensió dels seus materials. Des de la temporada 2016 ofereix els resums argumentals de les òperes en format de lectura fàcil per obrir els seus espectacles a tots els públics. Segueix així la línia d'accessibilitat iniciada des que el 2015 va apostar per incloure les pautes de lectura fàcil en la renovació de la senyalística de tot el teatre.

Però com succeeix en l'àmbit de l'Administració, tampoc existeix un centre cultural que hagi arribat a l'adaptació global dels seus continguts. Certament, en l'organització de la Jornada Internacional de lectura fàcil, per a la taula
Però tot i aquests

exemples, manca que

l'Administració

inclogui l'accessibilitat

als continguts com a

eix transversal en tota

la seva organització
Molts equipaments

culturals han

demanat la

col·laboració de l'ALF

per adaptar textos de

sala, catàlegs i

dossiers educatius per

tal de garantir

l'accessibilitat

cognitiva en les seves

exposicions 
rodona dedicada a cultura, tampoc es va trobar cap equipament internacional que apostés clarament per l'accessibilitat universal dels seus continguts.

Es tracta, doncs, d'un procés lent i que exigeix molta cura, que implica un canvi d'estructura global on cal incorporar diferents mesures, com ara una persona encarregada de l'accessibilitat dins de cada equipament.

\subsection{Mancances d'accessibilitat als textos legals}

Si a les administracions o al sector cultural manca un projecte global, en altres àmbits les mancances són més flagrants. És el cas del sector legal i judicial, un àmbit en el qual la lectura fàcil és imprescindible perquè ajudaria el conjunt de la població a entendre el llenguatge excessivament tècnic d'aquest sector.

Durant el 2018-2019 en diferents territoris de l'Estat s'han succeït les sentències en lectura fàcil. No és el cas de Catalunya:

- Audiència Provincial de Madrid: «El Tribunal dicta una sentencia de lectura fácil para una persona con discapacidad víctima de una estafa» (Octubre 2018)

- Jutjat número 1 d’Oviedo «Asturias adapta la lectura fácil por primera vez en España una sentencia del orden ContenciosoAdministrativo» (Març 2019)

\section{CONCLUSIONS}

Finalitzat aquest recorregut per conèixer l'evolució de la lectura fàcil a nivell nacional i internacional durant els anys 2018 i 2019, podem extreure'n les següents afirmacions a tall de conclusions:

- La lectura fàcil abraça diverses realitats amb un mateix objectiu. Després de més de 15 anys de la creació de la Xarxa Internacional de Lectura Fàcil, constatem que la lectura fàcil ha evolucionat de manera diversa a cada país, però sempre amb un mateix objectiu: fer accessible la lectura, la cultura i la informació per a totes les persones.

- La biblioteca és un referent d'accessibilitat lectora.

Les biblioteques han estat i són un dels principals motors d'impuls de la lectura fàcil a Catalunya. Per la seva banda, els clubs de lectura fàcil es consoliden com a activitat de foment de la lectura i també de millora de la qualitat de vida dels seus participants.

- El dret a rebre una informació clara.

L'accés a la informació, el coneixement i la cultura és un dret que cal garantir a tots els ciutadans perquè puguin participar de forma activa
Es tracta, doncs, d'un

procés lent i que

exigeix molta cura, que implica un canvi d'estructura global

L'accés a la

informació, el

coneixement i la

cultura és un dret que

cal garantir a tots els

ciutadans perquè

puguin participar de

forma activa i

responsable en la

societat 
i responsable en la societat. Diverses lleis recullen l'obligatorietat de suprimir les barreres de la comunicació i algunes administracions públiques comencen a fer les primeres passos en aquest sentit, però encara queda molt camí per recórrer.

- La cultura a l'abast de tothom.

El sector cultural (museus, teatres, centres culturals, etc.) ha fet una aposta decidida per oferir els seus continguts en formats accessibles i d'aquesta manera poder obrir-se a nous públics i fer un pas més a favor de la inclusió social.

\section{BIBLIOGRAFIA}

"Avaluació dels clubs de lectura fàcil: estudi d'impacte: octubre 2017." Diputació de Barcelona, 2018.

Catalunya. Decret 150/2017, de 17 d'octubre, de l'atenció educativa a l'alumnat en el marc d'un sistema educatiu inclusiu. (DOGC [en línia], núm. 7477, 19-10-2017).

<https://portaldogc.gencat.cat/utilsEADOP/PDF/7477/1639866.pdf>.

[Consulta: 27 febrer 2021].

Catalunya. Llei 13/2014, del 30 d'octubre, d'accessibilitat. (DOGC [en línia], núm. 6742, 4-11-2014).

<http://portaldogc.gencat.cat/utilsEADOP/PDF/6742/1379017.pdf>.

[Consulta: 27 febrer 2021]. 


\section{Disponible a:}

https://revistes.ub.edu/index.php/Anuari-BLL/article/view/33994

Serra, Elisabet; Vidal, Laia. «La lectura fàcil a Catalunya (2018-2019)».

Anuari de Biblioteques, Llibres i Lectura, vol. 6 (2020), p. 219-231.

DOI 10.1344/ABLL.2020.6.012

Llicència Creative Commons

Reconeixement - NoComercial - SenseObraDerivada

(by-nc-nd): No es permet un ús comercial de l'obra

original ni la generació d'obres derivades.

(c) (1) 9 


\title{
ANUARI
}

\section{DE BIBLIOTEQUES, \\ LLIBRES I LECTURA}

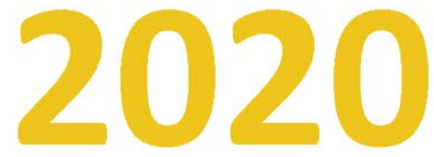

\section{Editors}

\author{
Lluís Agustí \\ Maite Comalat
}

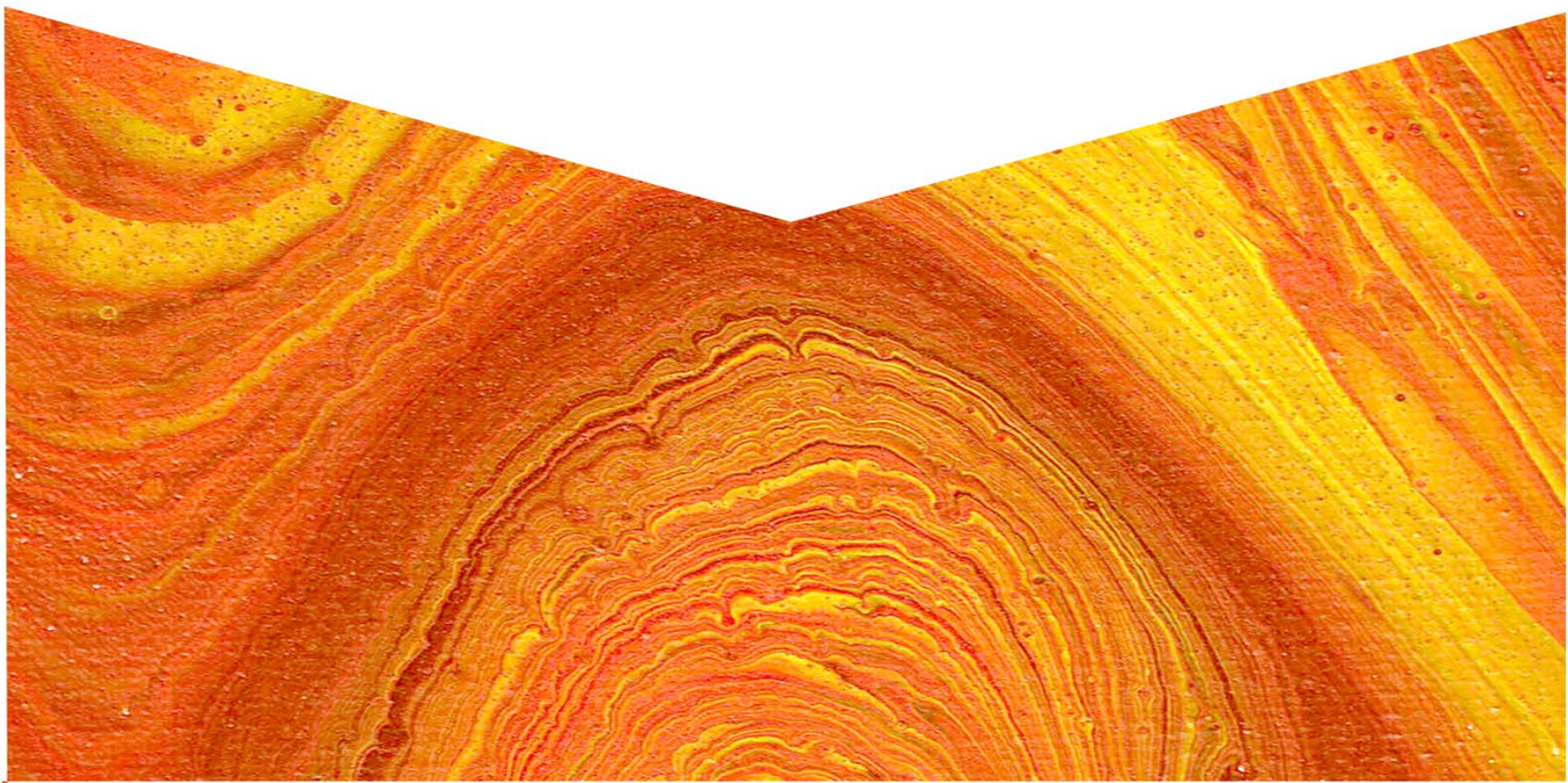

